\title{
Underutilised Indigenous Vegetables' (UIVs) Business in Southwestern Nigeria: Climate Adaptation Strategies
}

\author{
V. A. Tanimonure
}

\section{Contents}

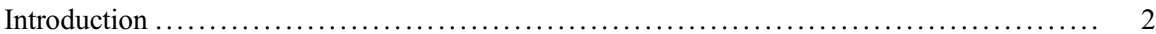

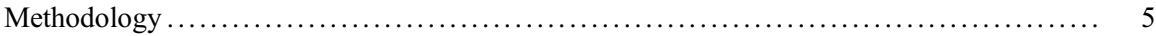

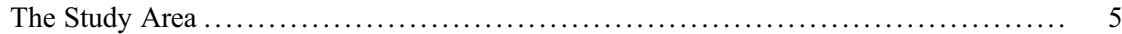

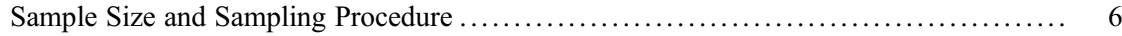

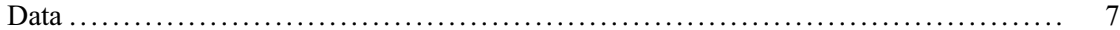

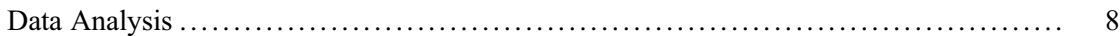

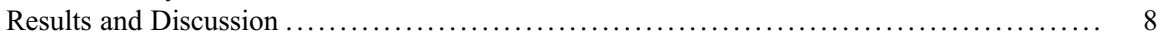

Farmers' Perception of Climate Change ..................................... 8

Comparison of Responses of UIVs to Changes in Rainfall ......................... 13

Adaptation Strategies Adopted by the UIVs Farmers ........................... 17

Variable Description of Adopters and Nonadopters of UIVs Producers ................ 18

Determinants of the Decision of UIVs Farmers to Adopt Climate Change Adaptation

Strategies ............................................................. 19

Conclusion and Recommendations ......................................... 19

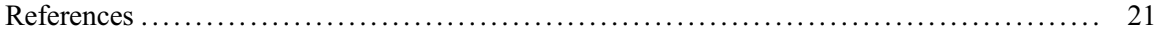

V. A. Tanimonure ( $\triangle)$

Agricultural Economics Department, Obafemi Awolowo University, Ile-Ife, Nigeria e-mail: tanimonurevic@oauife.edu.ng 


\section{Abstract}

The impact of climate change, especially on agricultural sector, calls for a global and more localized strategies such as cultivation of underutilized indigenous vegetables (UIVs) which adapt better to local climate change. This chapter, therefore, examines the perception of UIVs farmers to climate change, their experiences of UIVs' responses to climate change, adaptation strategies employed, and the determinants of the decision to adopt them in Southwest Nigeria. The study uses quantitative and qualitative primary household data from 191 UIVs farmers, 8 Focus Group Discussions (FGDs), and secondary climate data from the Nigerian Meteorological Agency. Descriptive and econometric analyses are employed in the data analyses. The results show that farmers' perceptions of climate change are high temperature and a high variability in rainfall pattern that has affected the yield, increased insects, pests, and diseases infestations, and reduced soil fertility. The results further show that the responses of UIVs to these resultant effects differ as such, and adaptation strategies farmers adopt are UIVs-specific. The adaptation strategies mostly employed by the UIVs farmers are cultivating UIVs along the river bank and the least is agroforestry and perennial plantation. The determinants of the decision to adopt adaptation strategies include UIVs revenue, age, years of experience, access to climate information, climate change awareness, agro ecological zone, and access to credit. Thus, promotion of UIVs business is advocated and provision of information on climate change essential and will encourage farmers to adopt appropriate climate change adaptation strategies to boost UIVs business.

\section{Keywords}

Climate change - Adaptation strategies · Underutilized - Indigenous vegetables · Nigeria

\section{Introduction}

The impact of climate change forecast on agriculture has posed a threat to the sustainability of global food security and nutrition. For instance, over half a billion (525 million) people in the tropics were projected by Consortium of International Agriculture Research (CGIAR) program on Climate Change Agriculture and Food Security (CCAFS) to possibly be at the perils of hunger by 2050 due to climate change (Actionaid International 2011). Intergovernmental Panel on Climate Change (IPCC) (2014) also predicted climate change increasing current problems and also generating new ones for natural and human systems. Likewise, Boko et al. (2007) predicted that reductions in yield of up to $50 \%$ in some countries in Africa by 2020 and net crop revenue by as much as $90 \%$ by 2100 could be attributed to climate change, smallholder farmers being mostly affected, especially the rural farmers who 
depend largely on rain-fed agriculture (Ching and Stabinsky 2011). Until adaptive or palliative measures are inaugurated to mollify the effects of climate change, food security in developing countries in the tropics, particularly in Nigeria, will be under threat (Enete 2014), considering the high rate of population growth.

Owing to the undesirable effects of climate change, it is suggested that a blend of global and more localized strategies, along with other adaptation strategies, can help farmers weather the effects of climate change. These include conservation agriculture, organic agriculture, carbon sequestration and the capacity to withstand weather stresses, change in planting time, the breeding of a number of climate-resilient crop varieties such as underutilized indigenous vegetables (UIVs), among others (Howden et al. 2007; Omatseye 2009; Sambo 2014). Underutilized indigenous vegetables are vegetables that originate from a locality; such vegetables may be localized to that particular area or found in other places. They are reported to be grown more widely or intensively in the past but are falling into disuse for a number of agronomic, genetic, economic, and cultural reasons. They are promising species but their potentials in terms of economic, nutrition, medicinal, and resilience have not been fully harnessed. Farmers, marketers and consumers are not making the best use of these crops as much as they use others because they are less competitive compared with other crops in the same agricultural environment (Guarino 1997; Eyzaguirre et al. 1999; IPGRI 2002; Padulosi and Hoeschle-Zeledon 2004). More so, these vegetables have not been a subject of organized research until recently (Tanton and Haq 2008). For instance, in the recent times, the production, marketing, and consumption of some of these vegetables are promoted in Southwest Nigeria in projects tagged NiCanVeg and MicroVeg. Some studies also reported that these UIVs are more adaptive, resilient, and tolerant to adverse climatic conditions than exotic species (Raghuvanshi and Singh 2001; Nnamani et al. 2009; Mabhaudhi et al. 2016).

In comparison to other crops, vegetables generally are more susceptible to environmental extremities such as high temperatures and soil moisture stress. Carbon dioxide, a major greenhouse gas, influences their growth and development as well as incidence of insect pests and diseases that render vegetable production unprofitable (Devi et al. 2017; Abewoy 2018). And all these will increase in the face of climate change (Ayyogari et al. 2014). However, UIVs can be produced comparatively at lower management cost, on marginal soil, and can tolerate the dynamics of climate change better than the exotic vegetables (Raghuvanshi and Singh 2001; Nnamani et al. 2009; Padulosi et al. 2011). This offers a significant opportunity for poor people in the rural areas to withstand the effect of climate change and increase their revenue, and, thereby, be food and nutrition secure (Maroyi 2011; Ebert 2014). This is because many UIVs from the tropics are already well adapted to the climatic conditions, and, as such, respond better to climatic conditions.

Unfortunately, there is limited quantitative and qualitative information supporting all these claims (Padulosi et al. 2011; Intergovernmental Panel on Climate Change (IPCC) 2014; Chivenge et al. 2015). The knowledge of UIVs adaptation to climate change remains concealed in the indigenous knowledge systems and this may 
explain why certain communities have continued to preserve and utilize certain UIVs. The limited quantitative empirical information indicates that UIVs remain under-researched as well. Although, some studies identified the potentials of these neglected and underutilized crops in sub-Saharan Africa in the recent times. A research by Adebooye and Opabode (2004), for example, was particular about the conservation of these indigenous crops in order to prevent them from going into extinction, especially as the reliance on a handful of major crops has innate agronomic, nutritional, and economic risks, which is not sustainable in the long run (Ebert 2014). Ayanwale et al. (2011) and Aju et al. (2013) also studied the market potentials of some of these underutilized indigenous vegetables and envisaged good commercial prospect in them, especially for women folks who are resource constrained. Some of the representatives of these leafy vegetables, tuber crops, cereals, and grain legumes that fit into the class of underutilized crops were identified by Maroyi (2011), Shrestha (2013), and Chivenge et al. (2015). It was equally found out that they are potential future crops for smallholder farmers, as sources of nutrition and income, especially in this era of climate change. Study by Sambo (2014) showed that underutilized crops could offer scientists a rich source of genetic materials for modification, which could hold potential key to developing resilient and drought-tolerant crops. Recent research found out that these underutilized indigenous crops have the ability to grow under water-scarce conditions and that the key to future food and nutrition security may lie in their untapped potentials (Mabhaudhi et al. 2016). More recent research shows qualitatively that climate change has both positive and negative effects on indigenous vegetables and the predicted negative effect cannot be overemphasized (Chepkoech et al. 2018). Indigenous vegetables farmers, therefore, adopt a number of adaptation strategies to mitigate the effect of climate change on their production activities. Although Fadairo et al. (2019) examined the perceived likelihood impact and adaptation of vegetables farmers to climate change, their emphasis was not on indigenous vegetables which is the focus of this study. Their study advocated for locality-specific climate change adaptation strategies.

The Intergovernmental Panel on Climate Change (IPPC) defines adaptation as "any adjustment in natural or human systems in response to actual or expected climatic stimuli or their effects which moderates harm or exploits beneficial opportunities." Climate adaptation is termed as a correct adjustment to climate variability and change, especially for smallholder farmers to enhance resilience or reduce vulnerability to its effects (Fadairo et al. 2019).

This study, therefore, aims to examine the perception of UIVs' farmers and the responses of UIVs to climate variability and change in the study area. It assesses the adaptation strategies adopted by the farmers to cope with the adverse effects of climate change and lastly, analyzes the determinants of the decision to adopt adaptation strategies by the UIVs farmers. This will add to the existing literature on the resilience of underutilized indigenous vegetables to climate variability and change in sub-Saharan Africa. 


\section{Methodology}

\section{The Study Area}

The study area is South west region of Nigeria as presented in Fig. 1. The area lies between longitude $2^{\circ} 31^{1}$ and $6^{\circ} 00^{1}$ east and latitude $6^{\circ} 21^{1}$ and $8^{\circ} 37^{1}$ norths. The study area is bounded in the east by Edo and Delta States, in the north by Kwara and Kogi States, in the west by the Republic of Benin, and in the south by the Gulf of Guinea. The region constitutes about one sixth $\left(\sim 163,000 \mathrm{~km}^{2}\right)$ of the total land area of Nigeria and comprises six states (Oyo, Ogun, Osun, Ondo, Ekiti, and Lagos) and is distinctly divided into three major agro-ecological zones (Rain Forest zone, Swamp Forest zone, and Derived Savannah zone) with diverse climatic conditions. The forest agro-ecological zone has annual rainfall in the range of 1,600-2,400 mm, with cropping seasons between April and November, while dry spells occur from December to March. The soil types in this zone depend largely on parent rock; where the underlying rocks are granite or clay, the soil is a rich clayey loam. On the other hand, the derived savannah agro-ecological zone has mean annual rainfall ranging from 800 to $1,500 \mathrm{~mm}$, with cropping seasons between June and November. The soil types range from the sandy to clayey in texture, with soil reaction ranging from acidic to slightly basic. Soil fertility statuses and crop species diversity also vary widely in different locations in the region. This study is carried out in two of the three agro-ecological zones: Rain Forest and Derived Savannah zones, where UIVs were promoted in a project tagged NiCanVeg.

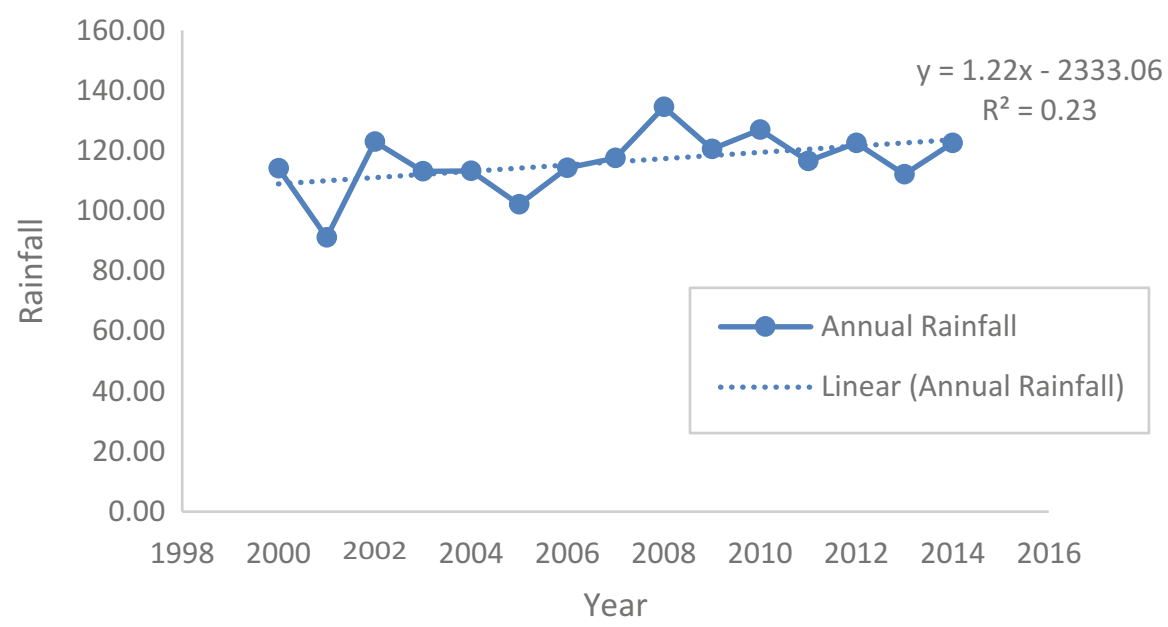

Fig. 1 Annual rainfall trend in Southwest Nigeria 


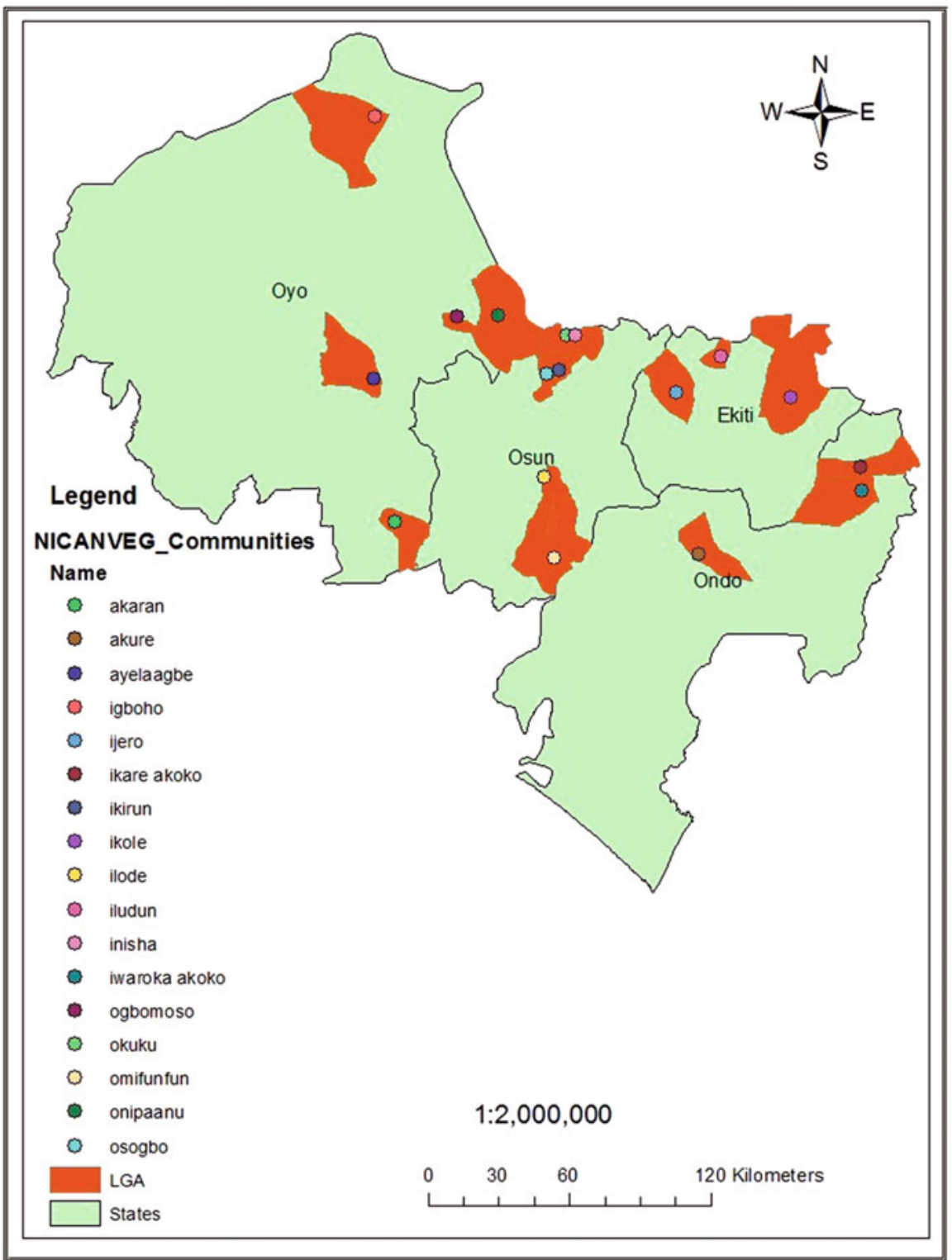

\section{Sample Size and Sampling Procedure}

All the 17 NiCanVeg communities in 16 Local Government Areas (LGAs) of the four (Ekiti, Ondo, Osun, and Oyo) states were selected for this research. In order to 
ensure representativeness and due to limited budget, a simplified formula (Eq. 1) developed by Kothari (2004) was used to calculate the sample size of the respondents at the community level. A 95\% confidence level, 5\% estimated percentage, and $P=0.5$ were assumed in the equations.

$$
\mathrm{n}=\frac{Z^{2} X p X q X N}{e^{2} X(N-1)+Z^{2} X p X q}
$$

where

$\mathrm{n}$ is the sample size

$N$ is the population size

$e$ is the estimated proportion

$p$ is sample proportion, $q=1-p$

$z$ is the value of the standard variate at a given confidence level and to be worked out from Table showing area under Normal Curve.

Based on this formula, the respondents' sample size is approximately 191 (which was about $50 \%$ of the direct beneficiaries of NiCanVeg project in the study area).

In each NiCanVeg site, the NiCanVeg farmers were stratified into male and female to ensure random selection of both sexes, and $50 \%$ of the total farmers were randomly selected from NiCanVeg farmers' lists. This proportionate sampling procedure was necessary because of the difference in the number of farmers in each community or site.

\section{Data}

The mixed-methods research design involving both the quantitative and qualitative research approaches were employed to elicit information from the respondents. The quantitative study involved face-to-face data collection with the use of structured questionnaire. The questionnaire administration was done by the trained enumerators to ensure the quality of the data. Before the data collection, there was an "advance notification" sent to the respondents to let them know that the survey would be conducted in their communities. The enumerators were led to the communities by the NiCanVeg field officer who was already familiar with the farmers and the communities. Two Focus Group Discussions (FGDs) per state were conducted among the UIVs farmers to gather the qualitative data used for the study. The data collected include UIVs' household socioeconomic characteristics, their perception of climate change, and the various adaptation strategies adopted over the years to mitigate the effects of climate change, information on various vegetables they cultivate, the reasons why they cultivate the vegetables, and the responses of the vegetables to the perceived negative effects of climate variability in the study area. The FGDs with the farmers generated information on the type of vegetables cultivated across the four states, their order of economic importance, and 
the responses of these vegetables to resultant or indirect effects of climate change variables (rainfall and temperature) such as drought, flood, insect infestations, pests, and diseases. Farmers were asked to describe climate change variables expressed as changes in amount of rainfall and temperature on the extent of drought, changes in insect infestations, soil fertility, and UIVs yield. Also, UIVs producers' perceptions of climate change are compared with historical trends from Nigerian Meteorological data (average monthly temperature and rainfall) between 2000 and 2014.

\section{Data Analysis}

Both descriptive statistics and econometric analyses are used in the data analysis. Descriptive statistics such as frequency counts, means, and percentages are employed to describe the socio-economic characteristics of the respondents and the effects of climate change adaptation strategies on UIVs production. Content analysis was employed for the qualitative data collected through the FGDs. For the econometric analysis, logistic regression inferential statistic was used to analyze the factors affecting UIVs farmers' decisions to adopt adaptation strategy or not (Mahouna et al. 2018). In this study, the dependent variable is dichotomous, that is, farmers' decision to either adopt or not adopt climate change adaptation strategy. This method is appropriate because it considers the relationship between a binary dependent variable and a set of independent variables.

\section{Results and Discussion}

Table 1 summarizes the distribution of the UIVs that farmers cultivate in order of economic importance across the four States that the study covered. The summary reveals while good number of the UIVs are found across the entire region, only few UIVs are state specific. For instance, it is only in Osun State that red amaranth is produced in commercial quantity. Also, it is only in Oyo State (northern part) that Solanum zuccagnianum (locally called osun) is cultivated in commercial quantity. Aside Ondo State where ugu is the most economically important UIV, amaranth species remain the most economically viable UIV in the region. It is also noteworthy that respondents in Oyo State ranked two different UIVs as first economic important vegetables. While the UIVs producers in the northern part of the State ranked Solanum zuccagnianum as number one economically important UIV, those in the southern part ranked amaranth species as the number one in term of economic importance.

\section{Farmers' Perception of Climate Change}

Perception is the way something is regarded, understood, or interpreted. It is one of the first important steps in the process of designing some form of change in farmers' livelihood system to adapt to the changing climate. In order to get essential 
Table 1 Distribution of UIVs production in the study area

\begin{tabular}{|c|c|c|c|}
\hline Local name & English name & Scientific name & $\begin{array}{l}\text { Order of economic } \\
\text { importance }\end{array}$ \\
\hline \multicolumn{4}{|l|}{ Osun State } \\
\hline Tete Abalaye & White amaranth & Amaranth viridis & 1 \\
\hline $\begin{array}{l}\text { Red Tete/Tete } \\
\text { Ijesa }\end{array}$ & Red amaranth & Amaranth cruentus & 2 \\
\hline Ewedu & Jute mallow & Corchorus olitorius & 3 \\
\hline Ugu & Fluted pumpkin & Telfairia occidentalis & 4 \\
\hline Igbagba/Gboma & African eggplant & Solanum macrocarpon & 5 \\
\hline Worowo & Bologi & Solanecio biafrae & 6 \\
\hline Soko & Quail grass & Celosia argentea & 7 \\
\hline Waterleaf & Waterleaf & Talinum fruticosum & 8 \\
\hline Ebolo & Fire weed & $\begin{array}{l}\text { Crassocephalum } \\
\text { crepidoides }\end{array}$ & 9 \\
\hline Elegede & Field pumpkin & Cucurbita moschata & 10 \\
\hline Ogunmo & $\begin{array}{l}\text { Garden } \\
\text { huckleberry }\end{array}$ & Solanum scabrum & 11 \\
\hline
\end{tabular}

\section{Oyo State}

\begin{tabular}{l|l|l|l}
\hline Osun & - & Solanum zuccagnianum & 1 \\
\hline Tete Abalaye & White amaranth & Amaranth viridis & 1 \\
\hline Ogunmo & $\begin{array}{l}\text { Garden } \\
\text { huckleberry }\end{array}$ & Solanum scabrum & 2 \\
\hline Ewedu & Jute mallow & Corchorus olitorius & 3 \\
\hline Igbagba/Gboma & African eggplant & Solanum macrocarpon & 4 \\
\hline Soko & Quail grass & Celosia argentea & 5 \\
\hline Ugu & Fluted pumpkin & Telfairia occidentalis & 6 \\
\hline Odu & Black nightshade & Solanum nigrum & 7 \\
\hline Ebolo & Fire weed & $\begin{array}{l}\text { Crassocephalum } \\
\text { crepidoides }\end{array}$ & 8 \\
\hline
\end{tabular}

\section{Ondo State}

\begin{tabular}{l|l|l|l}
\hline Ugu & Fluted pumpkin & Telfairia occidentalis & 1 \\
\hline Igbagba/Gboma & African eggplant & Solanum macrocarpon & 2 \\
\hline Tete Abalaye & White amaranth & Amaranth viridis & 3 \\
\hline Soko & Quail grass & Celosia argentea & 4 \\
\hline Elegede & Field pumpkin & Cucurbita moschata & 5 \\
\hline Ogunmo & $\begin{array}{l}\text { Garden } \\
\text { huckleberry }\end{array}$ & Solanum scabrum & 6 \\
\hline Worowo & Bologi & Solanecio biafrae & 7 \\
\hline Odu & $\begin{array}{l}\text { Glossy } \\
\text { nightshade }\end{array}$ & Solanum nigrum & 8 \\
\hline
\end{tabular}

\section{Ekiti State}

\begin{tabular}{l|l|l|l}
\hline Abalaye & White amaranth & Amaranth viridis & 1 \\
\hline Igbagba/Gboma & African eggplant & Solanum macrocarpon & 2 \\
\hline Ugu & Fluted pumpkin & Telfairia occidentalis & 3 \\
\hline Ewedu & Quail grass & Celosia argentea & 4 \\
\hline
\end{tabular}


Table 1 (continued)

\begin{tabular}{l|l|l|l}
\hline Local name & English name & Scientific name & $\begin{array}{l}\text { Order of economic } \\
\text { importance }\end{array}$ \\
\hline Waterleaf & Fire weed & $\begin{array}{l}\text { Crassocephalum } \\
\text { crepidoides }\end{array}$ & 5 \\
\hline Odu & Field pumpkin & Cucurbita moschata & 6 \\
\hline Soko & Quail grass & Celosia argentea & 7 \\
\hline Worowo & Bologi & Solanecio biafrae & 8 \\
\hline Ogunmo & $\begin{array}{l}\text { Garden } \\
\text { huckleberry }\end{array}$ & Solanum scabrum & 9 \\
\hline
\end{tabular}

Source: Field survey, 2016

information and insight into farmers' perception of climate change, the two most important elements of climate rainfall and temperature are considered in this study. Out of the 191 sample respondents, only $10(5.24 \%)$ are of the opinion that there is no change in the climate as presented in Table 2. This result shows that farmers are well aware of climate change. This result is similar to Fadairo et al. (2019), who also found that awareness of climate variability and change was high among vegetables farmers.

\section{Farmers' Perception of Change in Rainfall Versus Meteorological Data}

The perception of UIVs farmers in the study area on the overall trend of average rainfall as presented in Table 2 shows that all the respondents who are aware of climate change perceived changes in the rainfall, although their perception of these changes differs. About $74 \%$ of the respondents perceived decrease in average rainfall; about $4 \%$ perceived increase in rainfall, while about $21 \%$ could not say categorically whether the rainfall increased or decreased, but noticed an erratic rainfall over the years. Only $1 \%$ are indifferent to the rainfall pattern. The trend analysis of rainfall from Meteorological data between 2000 and 2014 in the area under study is presented in Fig. 1. The trend shows that there is no particular trend in average annual rainfall, as the rainfall pattern has been erratic. In year 2000, the average annual rainfall is high and falls in 2001. In 2002, the rainfall increases, falls in 2003, remains a little steady in 2004, and falls in 2005. The highest average rainfall within the period under study is in 2008 and since then, the average annual rainfall keeps rising and falling, although the quantitative trend shows that there is increase in average annual rainfall amount in the study area. The result of regression analysis between rainfall and time shows that an increase in one-year period results in a corresponding increase in the amount of average annual rainfall by $1.22 \mathrm{~mm}$ (Fig. 1). However, the perception of most farmers of rainfall shows a view contrary to the information contained in the meteorological recorded data. The majority of UIVs producers perceived reduction in rainfall. This lack of congruence could be as a result of the farmers assessing rainfall in relation to the needs of UIVs at a particular time; small change in quantity, onset, and cessation of rain over days make a big difference in the hearts of farmers, whereas the Meteorological data is more likely to measure total and large effects (Lemmi 2013). 
Table 2 Farmers' perception on rainfall and temperature change

\begin{tabular}{l|l|l}
\hline Farmers' perception & Rainfall & Temperature \\
\hline No change & $10(5.24)$ & $10(5.24)$ \\
\hline Yes, increasing & $8(4.19)$ & $161(84.29)$ \\
\hline Yes, decreasing & $134(70.16)$ & $14(7.33)$ \\
\hline Erratic & $38(19.90)$ & 0 \\
\hline Indifference & $1(0.52)$ & $6(3.14)$ \\
\hline
\end{tabular}

Source: Field survey, 2016

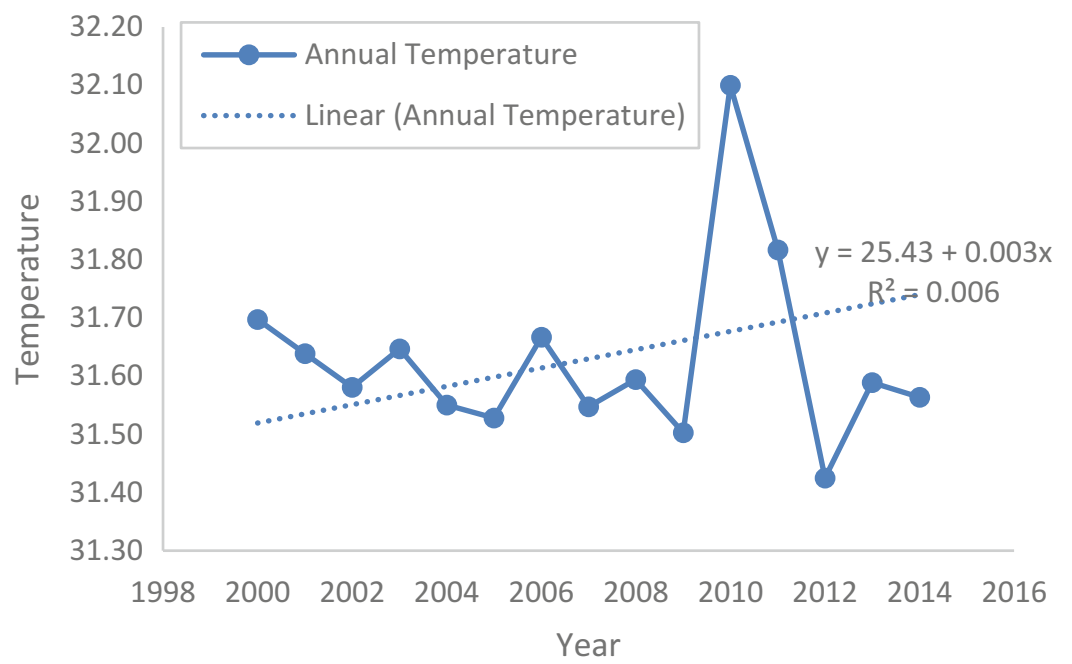

Fig. 2 Annual temperature trend in Southwest Nigeria

\section{Farmers' Perception of Change in Temperature Versus Meteorological Data}

In the case of average temperature, all the UIVs farmers who are aware of climate change perceived changes in average temperature over the years (Table 2). Majority $(88.95 \%)$ of UIVs producers perceived increase in average annual temperature in the study area. Only $8 \%$ perceived decrease in the temperature, while the remaining percentage of respondents (3.31\%) are indifferent to the changes in temperature. The trend analysis of the meteorological data of temperature between 2000 and 2014 shows an increasing trend. The regression between average annual temperature and time shows that an increase in one-year period results in an increase in the average temperature of the area by $0.003{ }^{\circ} \mathrm{C}$ (Fig. 2). Thus, farmers' perception appears to be in consonant with the statistical record of temperature from the meteorological station. This result is also in line with (Chepkoech et al. 2018), who also found increasing trend in the temperature of study area. 


\section{Farmers' Perception of Resultant Effects of Climate Change Variables}

The outcome of changes in average annual rainfall and temperature results into different anomalies such as drought frequency, insects, pests and diseases infestations, loss of soil fertility, reduction in yield, among others (Chepkoech et al. 2018). Table 3 presents the perception of UIVs farmers to some of these anomalies brought about by climate change in the study area in relation to UIVs production. About $88 \%$ of the UIVs producers believe that occurrence of drought has increased over the years as a result of reduction and/or erratic pattern of rainfall. The excerpts of the farmers during the FGDs further establish the negative effects of drought on the production activities of UIVs:

The erratic rainfall has brought problem to farmers because most of what we plant did not germinate on time and some even got burnt in the soil as a result of prolonged drought

FGD with Farmers in Ilesha, Osun State.

About $76 \%$ of the respondents indicated that the effect of insect infestation has increased greatly in recent times, compared to the past. The excerpts from the FGDs affirm this:

There is reduction in our output due to climate change; there are some insects destroying our farm produce. To the extent that we have to take some of the species of the insect to laboratory for the scientist to help us find solution to it because the insecticide we have been using are no longer effective

FGD with farmers in Ilesha, Osun State. ... also what we have experienced this year has never been experienced before. That we plant all vegetables and insect and pest spoilt some specific vegetables. Pest also spoilt all the maize and some other crops.

FGD with farmers in Ile-Ife, Osun State.

There is no positive impact. Our expectation has been dashed because there is irregularity in rainfall. Our profits are low, insects infested our farm and destroyed it

FGD with farmers in Iwaroka, Ekiti State.

Also, the response of UIVs farmers to the effect of climate change on soil fertility is negative. About $64 \%$ of the farmers are of the opinion that soil fertility has decreased greatly. More so, most (73.82\%) UIVs farmers experienced reduction in yield and, as a result of this, about $73 \%$ testified to the fact that this, invariably, has drastically reduced their earnings from UIVs production. Excerpts from the FGDs conducted buttress these facts thus:

Since there is irregularity in rainfall, we don't really get the normal output, so it has reduced our income

FGD with farmers in Igboho, Oyo State.

Although, there is good market for vegetables now, but the insect infestation has reduced our output which resulted in low income, and this had brought financial difficulties on farmers

FGD with farmers in Ilesha, Osun State. 
Table 3 UIVs farmers' perception of resultant effects of climate change variables

UIVs farmers' perceived effects of climate change Frequency Percentage

Change in drought

\begin{tabular}{l|l|c}
\hline No change & 0 & 0.00 \\
\hline Yes, increasing & 161 & 88.29 \\
\hline Yes, decreasing & 14 & 7.33 \\
\hline Indifference & 6 & 3.14 \\
\hline No response & 10 & 5.24 \\
\hline
\end{tabular}

Change in pests and insects infestation

\begin{tabular}{l|l|c}
\hline No change & 0 & 0.00 \\
\hline Yes, increasing & 145 & 75.92 \\
\hline Yes, decreasing & 16 & 8.38 \\
\hline Indifference & 11 & 5.76 \\
\hline No response & 19 & 9.95
\end{tabular}

\section{Change in Soil fertility}

No change

Yes, increasing

Yes, decreasing

Indifference

No response

\begin{tabular}{|l|r|}
\hline 0 & 0.00 \\
\hline 28 & 14.66 \\
\hline 122 & 63.87 \\
\hline 31 & 16.23 \\
\hline 10 & 5.24 \\
\hline
\end{tabular}

Change in UIVs Yield

\begin{tabular}{l|l|c}
\hline No change & 0 & 0.00 \\
\hline Yes, increasing & 36 & 18.85 \\
\hline Yes, decreasing & 141 & 73.82 \\
\hline Indifference & 4 & 2.09 \\
\hline No response & 10 & 5.24 \\
\hline
\end{tabular}

Change in annual Earnings

\begin{tabular}{l|l|c}
\hline No change & 0 & 0.00 \\
\hline Yes, increasing & 36 & 18.85 \\
\hline Yes, decreasing & 139 & 72.77 \\
\hline Indifference & 5 & 2.62 \\
\hline No response & 11 & 5.76
\end{tabular}

Changes in the Land area allotted to UIVs

\begin{tabular}{l|l|c}
\hline No change & 0 & 0.00 \\
\hline Yes, increasing & 129 & 67.54 \\
\hline Yes, decreasing & 50 & 26.18 \\
\hline Indifference & 1 & 0.52 \\
\hline No response & 11 & 5.76 \\
\hline
\end{tabular}

Source: Field survey, 2016

\section{Comparison of Responses of UIVs to Changes in Rainfall}

An understanding of the responses of UIVs to the indirect effect of climate change variables such as yield reduction, insect, pests, and diseases infestations is very crucial. This will guide farmers on the type of climate change adaptation strategies to 


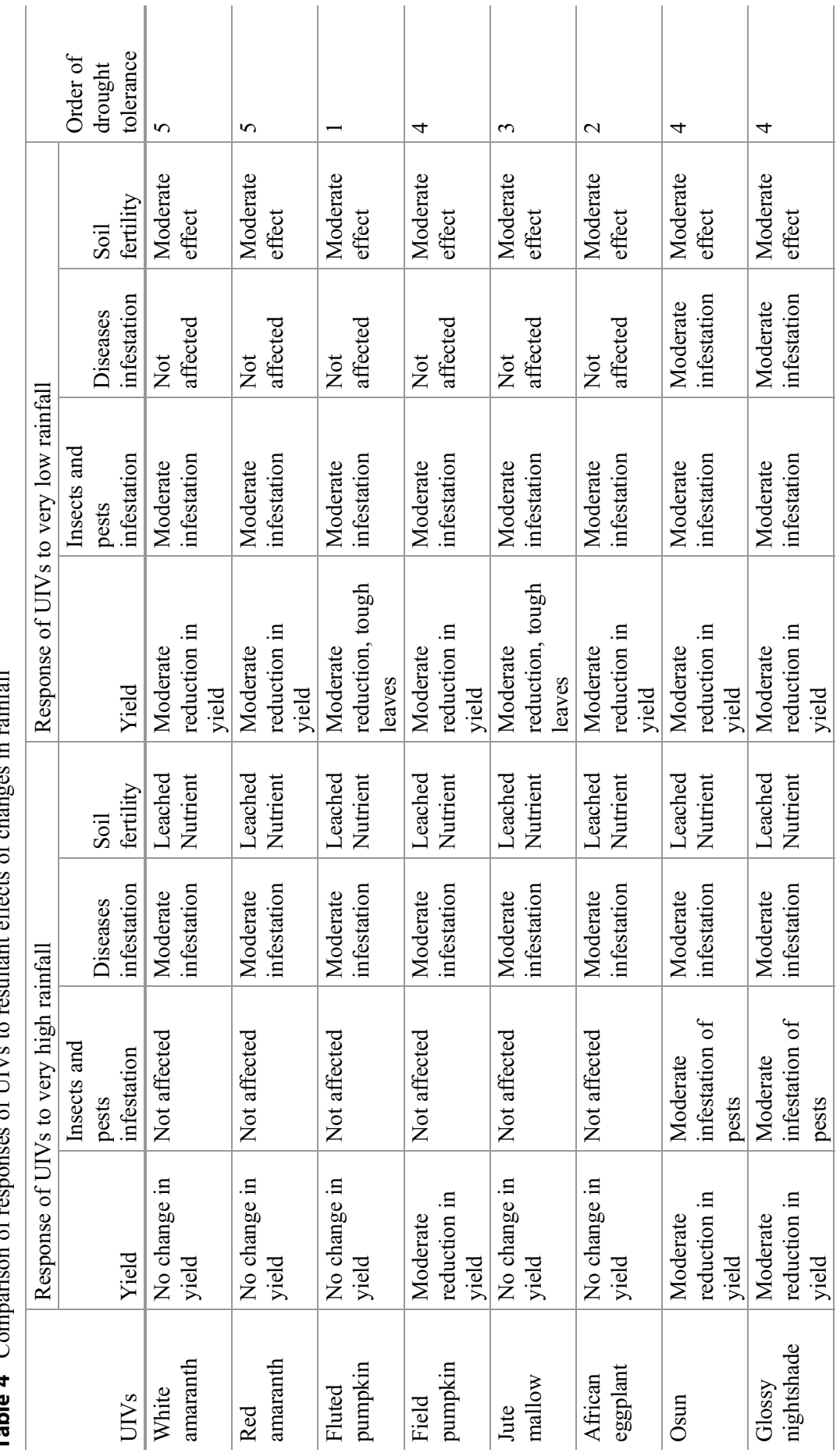




\begin{tabular}{|c|c|c|c|c|}
\hline$\nabla$ & 0 & $r$ & $a$ & $\infty$ \\
\hline 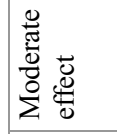 & 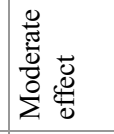 & 1 & 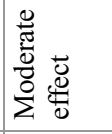 & 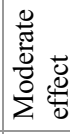 \\
\hline 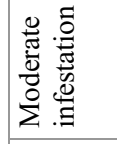 & 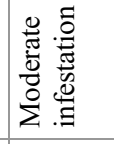 & 1 & 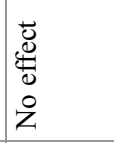 & 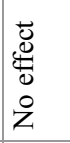 \\
\hline 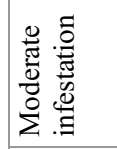 & 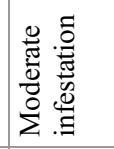 & 1 & 乙. & 乙. \\
\hline 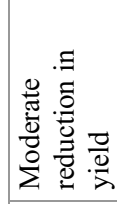 & 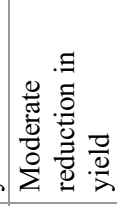 & 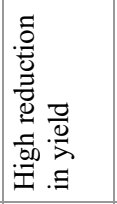 & 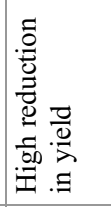 & 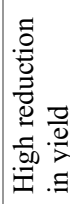 \\
\hline 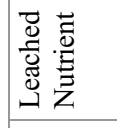 & 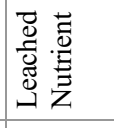 & 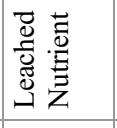 & 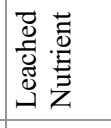 & 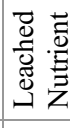 \\
\hline 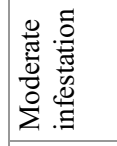 & 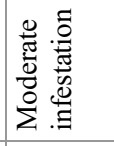 & 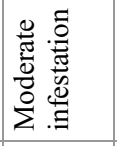 & z. & z. \\
\hline 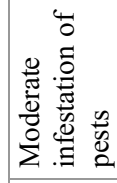 & 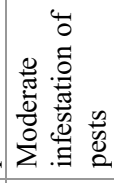 & 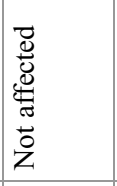 & 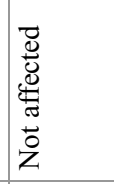 & 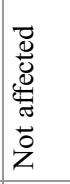 \\
\hline 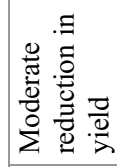 & 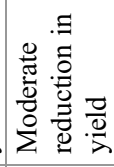 & 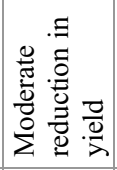 & 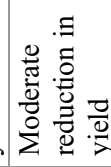 & 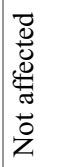 \\
\hline 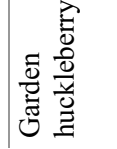 & 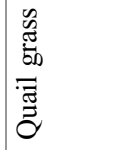 & 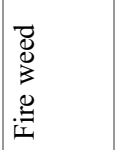 & $\begin{array}{l}\overline{0 D} \\
0 \\
\overline{0} \\
0\end{array}$ & 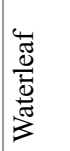 \\
\hline
\end{tabular}


adopt in order to reduce the negative impact of climate change on UIVs production. The responses of the farmers across the four States are harmonized and summarized in Table 4. Unanimously, the farmers across the four States agreed that the UIVs' response to resultant effects of climate change differs and it is premised on the type of UIVs and season. This finding is in an agreement with Chepkoech et al. (2018) who also found that the sensitivity of African Indigenous Vegetables to climate change variables is determined by the season and the type of vegetable, for instance, in the case of amaranth species, fluted pumpkin, jute mallow, and African eggplant; extreme rainfall does not really have effect on both their yield and the incident of insects and pests' infestations, although they experience moderate disease infestation such as yellowing of leaves. During the dry season, their yields are moderately low and moderate rate of pests and insects' infestation occur. The disease infestations are rare during this period for the vegetables.

During the high rainfall and low rainfall periods, osun, glossy nightshade, garden huckleberry, and quail grass are moderately affected in terms of yield, pests, insects, and disease infestations. In the case of field pumpkin and fire weed, there is moderate reduction in yield and disease infestation but not affected by pests and insects during the excessive rainfall period. Extremely low rainfall or dry spell reduced the yield moderately and the effect of insects and pests too is moderate and there is no disease infestation for field pumpkin. But for fire weed, the dry spell reduced the yield greatly; in fact, the fire weed may be totally unavailable in the market. While the yield of Bologi is moderately reduced by excessive rainfall, that of waterleaf is not affected. The two UIVs are not affected by insects and pests and diseases infestation during the extreme high and low rainfall but their yields are greatly reduced during the low rainfall. It is noteworthy that lots of nutrients are washed and leached away during the excessive rain fall period. From the result, it is obvious that excessive rainfall encourages diseases infestation while low rainfall or dry spell encourages insects and pests' infestation. The result is in harmony with Chepkoech et al. (2018) results. The ranking of the UIVs that are cultivated by the farmers in the study area in order of drought tolerance is also presented in Table 4; ugu is the most drought tolerant while Bologi is ranked last on the list.

Table 5 Adaptation strategies adopted by the UIVs farmers

\begin{tabular}{l|l|l|l}
\hline Adaptation strategy & Frequency & Percentage & Position \\
\hline No adaptation & 29 & 15.18 & 8 th \\
\hline Crop diversification & 51 & 26.70 & 3 rd \\
\hline Changing time of planting & 45 & 23.56 & 4 th \\
\hline Diversification to other nonagricultural activities & 121 & 63.35 & 2 nd \\
\hline Agroforestry and perennial plantation & 7 & 3.66 & 9 th \\
\hline Use of integrated pest management and use of fertilizer & 39 & 20.42 & 7 th \\
\hline Cultivating along river banks & 187 & 97.91 & 1 st \\
\hline $\begin{array}{l}\text { Good practices (mixed cropping, crop rotation, } \\
\text { mulching, organic fertilizer) }\end{array}$ & 44 & 23.04 & 5 th \\
\hline Irrigation & 41 & 21.47 & 6 th \\
\hline
\end{tabular}




\section{Adaptation Strategies Adopted by the UIVs Farmers}

A number of adaptation strategies are adopted by the UIVs farmers in order to weather the negative effects of climate change (Fadairo et al. 2019) presented in Table 4. The adaptation strategies adopted by the UIVs farmers are presented in Table 5 . From the Table, only about $15 \%$ of the farmers do not adopt any strategy. This result is similar to Mahouna et al. (2018), who also identified only $14.2 \%$ of the sample respondent as nonadopter of climate change adaptation strategy but at variance with Fadairo et al. (2019) who found that all vegetable farmers adopted one form of adaptation strategy or the other. From the discussion with the farmers, it was gathered that the most important adaptation strategies adopted by UIVs farmers over the years is to cultivate UIVs along the river bank during the dry season and use upland during the wet season to reduce the incident of diseases and flood from excessive high rainfall. About $98 \%$ adopt this strategy. The information gathered further reveals that about $63 \%$ of UIVs producers are diversifying from agriculture to nonagricultural related businesses as a result of their unpalatable experiences in farming. Some of the excerpts from the FGDs show that many farmers are discouraged as a result of some of their experiences. The third popular adaptation strategy option is crop diversification. About $27 \%$ of the respondents indicated crop diversification as adaptation strategy they have adopted. An excerpt from the FGD in IleIfe, Osun State, shows this:

... that was why I changed to okra plantation. When I tried it and it performed better, I decided to change to okra cultivation

FGD with farmers in Ile-Ife, Osun State

Also, 23.56\% changed time of planting, and about 23\% also adopted agricultural good practices such as mulching, crop rotation, and mixed cropping. About $21 \%$ adopted irrigation, but the excerpts from the FGD show that where rain failed, some adopted irrigation system and it led to outbreak of insect infestations which pesticide could not handle. The excerpt from the FGD in Osun State reveals this thus:

The first step we took when the rain did not fall was to use irrigation. Different pests and insect infestations showed up. We used different insecticides to kill the insects, but chemical compositions were no longer effective like before.

FGD with farmers in Ilesha, Osun State

It was noteworthy that the least (3.66\%) adaptation strategy adopted by the UIVs farmers is agroforestry and perennial plantation, and about $15 \%$ do not adopt any adaptation strategy. 
Table 6 Variables and summary statistics

\begin{tabular}{|c|c|c|c|c|c|}
\hline \multirow[b]{2}{*}{ Variable } & \multicolumn{2}{|l|}{ Nonadopters } & \multicolumn{2}{|l|}{ Adopters } & \multirow[b]{2}{*}{ Mean difference } \\
\hline & Mean & SD & Mean & SD & \\
\hline $\begin{array}{l}\text { Age of } \\
\text { respondent }\end{array}$ & 45.28 & 13.65 & 42.18 & 14.16 & $3.10 * * *$ \\
\hline $\begin{array}{l}\text { Years of formal } \\
\text { education }\end{array}$ & 9.07 & 4.80 & 9.23 & 4.68 & -0.17 \\
\hline $\begin{array}{l}\text { Years of UIVs } \\
\text { production } \\
\text { experience }\end{array}$ & 10.79 & 7.24 & 12.79 & 9.61 & $-2.00 * * *$ \\
\hline UIVs Land area & 0.11 & 0.18 & 0.22 & 0.49 & -0.12 \\
\hline $\begin{array}{l}\text { Access to } \\
\text { climate } \\
\text { information ( } 1 / \\
0)\end{array}$ & 0.48 & 0.51 & 0.73 & 0.45 & -0.25 \\
\hline $\begin{array}{l}\text { Agro ecological } \\
\text { zone }\end{array}$ & 0.69 & 0.47 & 0.85 & 0.36 & -0.16 \\
\hline Net revenue & $9,420,215$ & $14,100,000$ & $16,700,000$ & $27,020,000$ & $-7,276,625^{* * *}$ \\
\hline Off farm income & $5,47,848.30$ & $5,80,313.8$ & $1,043,479$ & $2,109,412$ & $-4,95,630.40 * * *$ \\
\hline $\begin{array}{l}\text { Average } \\
\text { monthly } \\
\text { temperature }\end{array}$ & 31.44 & 2.33 & 31.66 & 2.36 & -0.22 \\
\hline $\begin{array}{l}\text { Average } \\
\text { monthly } \\
\text { precipitation }\end{array}$ & 114.95 & 91.98 & 116.54 & 82.39 & $-1.59 * * *$ \\
\hline $\begin{array}{l}\text { Farm distance } \\
\text { from market }\end{array}$ & 5.60 & 4.02 & 6.12 & 4.57 & $-0.52 * * *$ \\
\hline $\begin{array}{l}\text { Farm distance } \\
\text { from main road }\end{array}$ & 1.70 & 1.58 & 2.21 & 3.41 & $-0.53 * * *$ \\
\hline
\end{tabular}

$* * *=$ Significant at $1 \%$ level

\section{Variable Description of Adopters and Nonadopters of UIVs Producers}

The description of the socioeconomic characteristics of UIVs farmers and other relevant variables to this study are summarized in Table 6 . The information provided in the table shows that the nonadopters are significantly older than the adopters. There is no significant difference between their years of formal education, UIVs vegetable land area, access to climate change information, agro-ecological zone, and average monthly temperature of adopters and nonadopters in the study area. Meanwhile, the adopters had significantly higher mean values of the years of UIVs production experience, net revenue from UIVs, off-farm income, average monthly precipitation, farm distances from market and main road than the nonadopters. 


\section{Determinants of the Decision of UIVs Farmers to Adopt Climate Change Adaptation Strategies}

Binary logistic regression analysis was used to analyze the determinants of the decision to adopt climate change adaptation strategies by the UIVs farmers in the study area. Variables such as revenue from UIVs, age, sex, household size, education, marital status of the respondents, vegetable farm size, farm distance to market and main road, experience in vegetable farming, access to climate information, climate change awareness, and agroecological zone are included in the analysis. The results of the analysis reveal that the revenue generated from the UIVs business has a positive and significant influence at the $1 \%$ threshold on the adoption of climate change adaptation strategy. The more the revenue generated from the business, the more likely the producer will be willing to adopt adaptation strategy. This implies that adoption of adaptation strategy is not free and resources for the implementation must be available for farmers to adopt. The age of UIVs producers is significant at $10 \%$ level but negative. The implication of this is that as farmers increase in age the likelihood of adopting adaptation strategy reduces. This finding is in line with Uddin et al. (2014), that as farmers age, they lose interest in adopting climate change adaptation strategy. The number of years of experience in UIVs farming has positive and significant relation at $10 \%$ threshold on the adoption of adaptation strategy. This is expected, and more experience implies more competence in weather forecasting. This outcome is similar to the result of Mahouna et al. (2018) who also found that the more the experience of farmers the more the likelihood of adopting climate change adaptation strategies. Access to climate information is also significant and has positive influence at the $5 \%$ threshold on adoption of adaptation strategy. This implies that the more access farmers have to sources of information on climate change, the more likely they will adopt adaptation strategy to ease the negative effect of climate change on their business. More so, awareness of climate change is significant at $1 \%$ level and has positive effect on the likelihood of farmers to adopt adaptation strategy. This means that when farmers are aware and well informed about climate, the likelihood to adopt adaptation strategy will not be difficult. Agro ecological zone too is significant and positively determines the likelihood of farmers adopting adaptation strategy. This suggests that the effect of climate change in various agro ecological zones differ and as such, the need for climate change adaptation strategy may also differ. Lastly, access to loan is significant at $10 \%$ level and positively relates to choice of adopting adaptation strategy. Those farmers who have access to loan will likely adopt adaptation strategy since the strategies are not free (Table 7).

\section{Conclusion and Recommendations}

This chapter presents a microlevel study on the perceived effect of climate change and adaptation strategy employed on UIVs business in Southwest Nigeria. To this end, data set from plot level survey of 191 UIVs farm was used in the analysis. UIVs 
Table 7 Determinants of the decision of UIVs farmers to adopt adaptation strategy

\begin{tabular}{l|l|l|c}
\hline Adoption & Odds ratio & Standard error & Z-value \\
\hline Revenue & 38.9202 & 55.3609 & $2.57^{* * *}$ \\
\hline Age of respondents & -0.9555 & 0.065 & $-1.64^{*}$ \\
\hline Sex of respondent & 1.9052 & 1.2175 & 1.01 \\
\hline Household size & 0.9895 & 0.0559 & -0.19 \\
\hline Years of formal education & 0.9603 & 0.0656 & -0.59 \\
\hline Marital status & 2.0791 & 2.3835 & 0.64 \\
\hline Experience in UIVs production & 1.0680 & 0.0416 & $1.69^{*}$ \\
\hline Access to climate information & 3.5169 & 1.9898 & $2.22^{* *}$ \\
\hline Vegetable land area & 3.3851 & 6.0988 & 0.68 \\
\hline Climate change awareness & 46.7125 & 39.6536 & $4.53^{* * *}$ \\
\hline Agro ecological zone & 3.0296 & 1.8863 & $1.78^{*}$ \\
\hline Farm distance to main road & 1.0304 & 0.1398 & 0.22 \\
\hline Farm distance to market & 0.9825 & 0.0710 & -0.24 \\
\hline Membership of association & 0.9301 & 0.5787 & -0.12 \\
\hline Access to loan & 4.4184 & 3.9790 & $1.65^{*}$ \\
\hline Constant & $-9.97 \mathrm{e}-11$ & $8.30 \mathrm{e}-10$ & $-2.77^{* * *}$ \\
\hline Logistic regression & $\begin{array}{l}\text { Number of observation }=191 \\
\text { Wald chi2 }(15)=63.84\end{array}$ & \\
& $\begin{array}{l}\text { Prob }>\text { chi2 }=0.0000 \\
\text { Pseudo R2 }=0.4018\end{array}$ & \\
\hline Log likelihood $=-47.5208$ & \\
\hline
\end{tabular}

$*, * *, * * *=$ Significant at $10 \%, 5 \%, 1 \%$ level, respectively

production activities, adaptation strategies information, and meteorological data were also obtained. In conclusion, 13 economically viable UIVs are identified across the study area and their responses to the indirect climate change effect such as insects, pests, and diseases infestation, soil fertility, drought and yield, differ. While some UIVs are not affected by these climate change effects, some are moderately affected and to some others, the effect was great. The study also concludes that the occurrence of insects and pests' infestations is common whenever rain cease to fall for a long time while diseases infestation is common during the excessive rainfall in the study area during the raining season. The study further concludes that UIVs farmers adopt nine different adaptation strategies to ameliorate the effect of climate change variables on the UIVs business. The most prominent of them is the cultivating UIVs along river banks and the least practiced is agroforestry and perennial plantation.

Finally, the study concludes that the factors that determine the likelihood of farmers to adopt climate change adaptation strategy are revenue from UIVs, age of UIVs farmer, years of experience in UIVs production, access to climate information, climate change awareness, agro ecological zone, and access to credit. From the conclusion, the following recommendations are made: 
- In the era of climate change, where many crops are failing, promotion of production, marketing, and consumption of UIVs is advocated for.

- Development of improved varieties of UIVs that are more tolerant to increased rainfall is needed.

- Information on climate change should be made available and accessible to farmers.

- Farmers should be trained on the right adaptation strategy to adopt, considering the type of crop they cultivate and the peculiarity of their agro-ecological zone.

Acknowledgments This work was supported by the UK Department for International Development under the Climate Impact Research Capacity and Leadership Enhancement (CIRCLE) Visiting Fellowship programme. Neither the findings nor the views expressed, however, necessarily reflect the policies of the UK Government.

\section{References}

Abewoy D (2018) Review on impacts of climate change on vegetable production and its management practices. Adv Crop Sci Tech 6(330):7. https://doi.org/10.4172/2329-8863.1000330

Actionaid International (2011) On the Brink: who's prepared for a climate and hunger crisis. Retrieved from http://www.actionaid.org/publications/brink-whos-best-prepared-climate-andhunger-crisis. 2011, in Third World News

Adebooye OC, Opabode JT (2004) Status of conservation of the indigenous leaf vegetables and fruits of Africa, 3(December), pp 700-705

Aju P, Labode P, Uwalaka R, Iwuanyanwu U (2013) The marketing potentials of indigenous leafy vegetables in southeastern Nigeria. Int J AgriSci 3(9):667-677. Retrieved from www.inacj.com

Ayanwale A, Oyedele D, Adebooye O, Adeyemo V (2011) A socio-economic analysis of the marketing chain for under-utilised indigenous vegetables in Southwestern Nigeria. In: African crop science conference proceedings, pp 515-519

Ayyogari K, Sidhya P, Pandit MK (2014) Impact of climate change on vegetable cultivation - a review. Int J Agric Environ Biotechnol 7(1):145-155. https://doi.org/10.5958/j.2230-732X.7.1. 020

Boko M, Niang I, Nyong A, Vogel C, Githeko A, Medany M (2007) Africa. In: Parry ML, Canziani OF, Palutikof JP, van der Linden PJ, Hanson CE (eds) Climate change 2007: impacts, adaptation, vulnerability. Contribution of working group II to the fourth assessment report of the intergovernmental panel on climate change. Cambridge University Press, Cambridge, UK

Chepkoech W, Mungai NW, Stöber S, Bett HK, Lotze-Campen H (2018) Farmers' perspectives: impact of climate change on African indigenous vegetable production in Kenya. Int J Clim Change Strat Manag 10(4):551-579. https://doi.org/10.1108/IJCCSM-07-2017-0160

Ching LL, Stabinsky D (2011) Ecological agriculture is climate resilient, Third World Network TWN Durban Briefing Paper (No. 1). Retrieved from www.twnside.org.sg

Chivenge P, Mabhaudhi T, Modi AT, Mafongoya P (2015) The potential role of neglected and underutilised crop species as future crops under water scarce conditions in sub-Saharan Africa. Int J Environ Res Public Health 12(6):5685-5711. https://doi.org/10.3390/ijerph120605685

Devi AP, Singh MS, Das SP, Kabiraj J (2017) Effect of climate change on vegetable production - a review. Int J Curr Microbiol App Sci 6(10):447-483. https://doi.org/10.20546/ijcmas.2017.610. 058

Ebert AW (2014) Potential of underutilized traditional vegetables and legume crops to contribute to food and nutritional security, income and more sustainable production systems. Sustainability (Switzerland) 6(1):319-335. https://doi.org/10.3390/su6010319 
Enete IC (2014) Impacts of climate change on agricultural production in Enugu state, Nigeria. J Earth Sci Clim Change 5(9):3. https://doi.org/10.4172/2157-7617.1000234

Eyzaguirre P, Padulosi S, Hodgkin T (1999) Priority setting for underutilized and neglected plant species of the Mediterranean region. In: Padulosi S (ed) IPGRI's strategy for neglected and underutilized species and the human dimension of agrobiodiversity. International Plant Genetic Resources Institute, Allepo, pp 1-20

Fadairo O, Williams PA, Nalwanga FS (2019) Perceived livelihood impacts and adaptation of vegetable farmers to climate variability and change in selected sites from Ghana, Uganda and Nigeria. Environ Dev Sustain. https://doi.org/10.1007/s10668-019-00514-1

Guarino L (1997) Traditional Africa vegetables: promoting the conservation and use of underutilized and neglected crops. In: Proceedings of the IPGRI International Workshop on Genetic Resources of Traditional Vegetables in Africa, Rome

Howden M, Soussana JF, Tubiello FN (2007) Adaptation strategies for climate change. Proc Natl Acad Sci 104:19691-19698

Intergovernmental Panel on Climate Change (2014) Climate change 2014 synthesis report summary chapter for policymakers. IPCC

IPGRI (2002) Neglected and underutilized plant species: strategic action plan of the International Plant Genetic Resources Institute, Rome

Kothari CR (2004) Research methodology, methods and techniques (second rev). New age International (P) Limited, Publisher, New Delhi

Lemmi LK (2013) Climate change perception and smallholder farmers' adaptation strategy: the case of Tole District, Southwest Showa Zone, Oromiya Regional State, Ehiopia. Department of Rural Development and Agricultural Extension, Haramaya University

Mabhaudhi T, O'Reilly P, Walker S, Mwale S (2016) Opportunities for underutilised crops in southern Africa's post-2015 development agenda. Sustainability 8(4):302. https://doi.org/10. 3390/su8040302

Mahouna A, Fadina R, Barjolle D (2018) Farmers' adaptation strategies to climate change and their implications in the Zou Department of South Benin. Environments 5(15):17. https://doi.org/10. 3390/environments5010015

Maroyi A (2011) Potential role of traditional vegetables in household food security: a case study from Zimbabwe. Afr J Agric Res 6(26):5720-5728. https://doi.org/10.5897/AJAR11.335

Nnamani C, Oselebe H, Agbatutu A (2009) Assessment of nutritional values of underutilized indigenous leafy vegetables of Ebonyi State, Nigeria. Afr J Biotechnol 8(9):2321-2324

Omatseye TR (2009, September 28) Speech by the Director General, NIMASA, at the 2009 World Maritime Day Celebrations, Abuja, Nigeria. In: Iwori J (ed) GLOBAL WARMING: poverty to worsen in Nigeria. THISDAY Newspaper, $\mathrm{p} 31$

Padulosi S, Hoeschle-Zeledon I (2004) Underutilized plant species: what are they? Leisa Margazine, 5

Padulosi S, Heywood V, Hunter D, Jarvis A (2011) Underutilized species and climate change: current status and outlook in crop adaptation to climate change. (eds: Yadav SS, Redden RJ, Hatfield JL, Lotze-Campen H, Hall AE). Blackwell, Oxford

Raghuvanshi RS, Singh R (2001) Nutritional composition of uncommon foods and their role in meeting in micronutrient needs. Int J Food Sci Nutr 32:331-335

Sambo BE (2014) Endangered, neglected, indigenous resilient crops: a potential against climate change impact for sustainable crop productivity and food security. J Agric Vet Sci 7(2):34-41

Shrestha D (2013) Indigenous vegetables of Nepal for biodiversity and food security. Int J Biodivers Conserv 5(March):98-108. https://doi.org/10.5897/JJBC11.124

Tanton T, Haq N (2008) Climate change: an exciting challenge for new and underutilized crops. In: Smartt J, Haq N (eds) New crops and uses: their role in a rapidly changing world. Centre for Underutilized Crops, University of Southampton, Southampton

Uddin MN, Bokelmann W, Entsminger JS (2014) Factors affecting farmers' adaptation strategies to environmental degradation and climate change effects: a farm level study in Bangladesh. Climate 2:223-241. https://doi.org/10.3390/cli2040223 
Open Access This chapter is licensed under the terms of the Creative Commons Attribution 4.0 International License (http://creativecommons.org/licenses/by/4.0/), which permits use, sharing, adaptation, distribution and reproduction in any medium or format, as long as you give appropriate credit to the original author(s) and the source, provide a link to the Creative Commons license and indicate if changes were made.

The images or other third party material in this chapter are included in the chapter's Creative Commons license, unless indicated otherwise in a credit line to the material. If material is not included in the chapter's Creative Commons license and your intended use is not permitted by statutory regulation or exceeds the permitted use, you will need to obtain permission directly from the copyright holder.

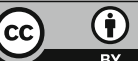

